American J. of Engineering and Applied Sciences 3 (1): 109-116, 2010

ISSN 1941-7020

(C) 2010 Science Publications

\title{
Repairing and Strengthening of an Existing Reinforced Concrete Building: A North Cyprus Perspective
}

\author{
Hakan Yalciner and Amir A. Hedayat \\ Department of Civil Engineering, Eastern Mediterranean University, \\ P.O. Box 95, Gazimagusa-North Cyprus, via Mersin 10 Turkey
}

\begin{abstract}
Problem statement: Inadequate attention during design and construction of some of Reinforced Concrete (RC) buildings in North Cyprus has raised questions about the performance level of these existing buildings under future earthquakes. Approach: Column jacketing, adding steel braces and new shear walls to an existing building are common strengthening methods used by practical engineers in North Cyprus to increase the performance level of an existing building. Results: The aim of this study was to determine the most effective strengthening method among these three mentioned techniques. As a case study, a four stories RC existing building was selected and assessed using finite element method. To remodel of the existing building, the survey works done included three main steps, detecting the reinforcement bars for beams and columns, actual used concrete strength and soil type. The beams and columns reinforcement bars were determined using Ferro scan method and the soil was sampled in Girne city to determine the soil type. The actual concrete strength was determined using core test. Three common strengthening techniques mentioned above, were applied to the existing building. Then the efficiency of each strengthening method was investigated on the basis of removing of weak columns, not-safe beam-column joints in shear and performance levels based on the FEMA356 and Turkish earthquake code. Conclusion/Recommendations: Results showed that column jacketing is the most effective method to remove the weak columns and not-safe column-beam joints in shear. Nonlinear static pushover results showed that despite that adding shear walls caused an increase in the structural base shear and a reduction in the maximum roof displacement and the number of collapsed elements at FEMA356 performance point, but it caused a remarkable reduction in the building ductility ratio. Finally, results showed that the column jacketing is the most effective and the most economic strengthening technique for the low-rise residential buildings in North Cyprus.
\end{abstract}

Key words: Jacketing columns, steel braces, adding new shear walls, push over analysis

\section{INTRODUCTION}

After several major seismic events that occurred in the recent past, such as the 1989 Loma Prieta and the 1994 Northridge earthquakes, the structural engineering community and building owners began to question the effectiveness of current building codes to protect property. However, there are other reasons for poor performance of buildings during earthquakes such as less quality of concrete, inadequate attention to joints during design and construction, poor workmanship and no soil classification tests before structural analysis. A performance objective involves the combination of the structure's expected performance level with a seismic hazard (Bertero and Bertero, 2002). In rehabilitation guidelines usually the performance levels are classified as Immediate Occupancy (IO), Life Safety (LS) and
Collapse Prevention (CP). Each structural performance level is associated with a damage state that can be observed or quantified. For instance, FEMA 356 (2000) defines LS and CP for reinforced concrete wall buildings when roof drift is equal to 1 and $2 \%$ of the building height respectively. Another assessment procedure was proposed by Sucuoglu (2006), where the performance levels are identified with their damage limits. Damage limits of the structural elements classified as Minimum damage limit (MN), Safety limit (SF) and Collapse Limit (CL). In both steel and concrete structures, the beamcolumn joints play a significant role in the performance of building. However in North Cyprus practical engineers do not enough pay attention to joints during design and construction.

Column jacketing, adding steel braces and new shear walls to an existing building are common

Corresponding Author: Hakan Yalciner, Department of Civil Engineering, Eastern Mediterranean University, P.O. Box 95, Gazimagusa-North Cyprus, via Mersin 10 Turkey 
strengthening methods used by practical engineers in North Cyprus to increase the performance level of an existing building. The aim of this study was to investigate the effect of not safety joints on the performance of a Reinforced Concrete (RC) building and to determine the most effective strengthening method among the three mentioned techniques. For this purpose an existing four story RC building which was designed based on the Turkish earthquake code was selected. Firstly, necessary tests were done to determine the soil type and concrete strength class. Then the weak columns and not safety beam-column joints in shear were detected. Three common strengthening techniques, column jacketing, adding steel braces and adding new shear walls were used to remove the detected problems. At the end using the procedure proposed by Sucuoglu (2006) and FEMA 356 the building performances were compared with respect of using each strengthening technique to find out the most effective strengthening method.

\section{MATERIALS AND METHODS}

Existing building: Figure 1 shows the four stories existing RC building which was designed using Turkish earthquake code 1997. The dimension of the building plan is $13.2 \times 14.33 \mathrm{~m}$ with total height equal to $11.38 \mathrm{~m}$. Column sizes vary form $25 \times 50-25 \times 100$ $\mathrm{cm}$ whilst all beams have same size equal to $25 \times 60$ $\mathrm{cm}$. The slab thickness for all stories is $15 \mathrm{~cm}$. The existing building was placed in Girne city within the second degree earthquake zone $(\mathrm{A} 0=0.3 \mathrm{~g})$. The Importance factor (I) was taken one. In order to remodel of the existing building, the survey works done included three main steps, detecting the reinforcement bars for beams and column, actual used concrete strength and soil type.

The beams and columns reinforcement bars were determined using Ferro scan according to the procedure of 2007 Turkish earthquake code. The used steel grade was S420 (yield stress $=420 \mathrm{MPa}$ ). In order to determine the soil type, the soil was sampled in Girne city from the depth of $1.5 \mathrm{~m}$ under the ground. The physical properties of this soil have been summarized in Table 1. Particle size distribution was performed using hydrometer apparatus. As it is shown in Fig. 2 the percentage of clay is 63 , silt 33 and sand is 4 percent. Therefore according to the Unified Soil Classification System (USCS) the soil type of the existing building is selected silty clay. The actual concrete strength was determined using core test.

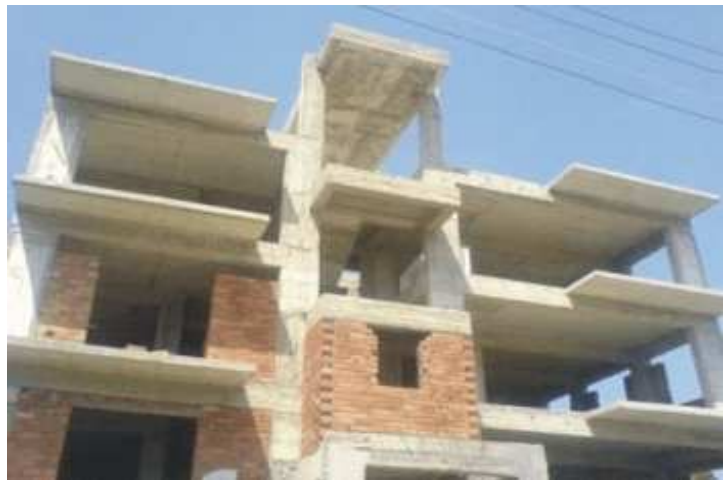

(a)

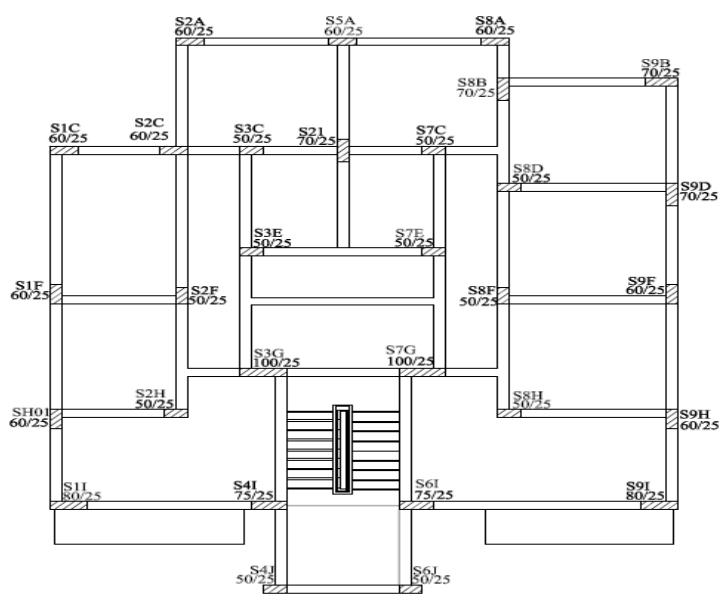

(b)

Fig. 1: Existing RC building: (a) front view; (b) plan

Table 1: Physical properties of soil

\begin{tabular}{lc}
\hline Soil characteristics & Soil D \\
\hline In situ dry density $\left(\mathrm{g} \mathrm{cm}^{-3}\right)$ & 1.480 \\
In situ water content (\%) & 29.270 \\
Liquid Limit (LL \%) & 63.270 \\
Plastic Limit (PL \%) & 31.900 \\
Plasticity Index (PI) & 31.370 \\
Shrinkage limit (SL \%) & 16.780 \\
Specific Gravity of solids (Gs) & 2.536 \\
Percentage of clay (\%) & 63.000 \\
Percentage of silt (\%) & 33.000 \\
Percentage of sand (\%) & 4.000 \\
Optimum water content $(\%)$ & 27.000 \\
Maximum dry density $\left(\mathrm{g} \mathrm{cm}^{-3)}\right.$ & 1.470 \\
Group symbol & On A-line $(\mathrm{CH}$ or $\mathrm{MH})$ \\
\hline
\end{tabular}

The core strength test provides in finding answers to the questions (a) Are the structural element of adequate strength? (b) Was concrete complying with the specification supplied to the construction?. Estimated strength can be calculated as follow:

strength $=\frac{\mathrm{F}}{1.5+\mathrm{D} / \mathrm{L}}$ 
Where:

$\mathrm{F}=$ Equal to 2.3 for vertical cores or 2.5 for horizontal cores

$\mathrm{D}=$ The diameter of the core

$\mathrm{L}=$ The length of the core after capping

The result of quality of concrete in the construction with correcting core strength for the influence of included steel factor (actual strength) is summarized in Table 2. Table 2 indicates that the selected concrete class during structural design was not used during construction of the existing structure which plays an effective role to decrease the performance level of the existing structure.

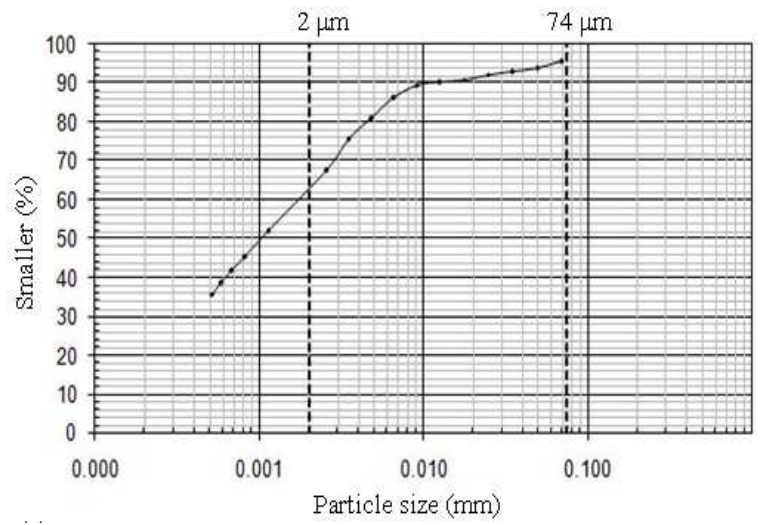

Fig. 2: Particle size distribution by hydrometer apparatus

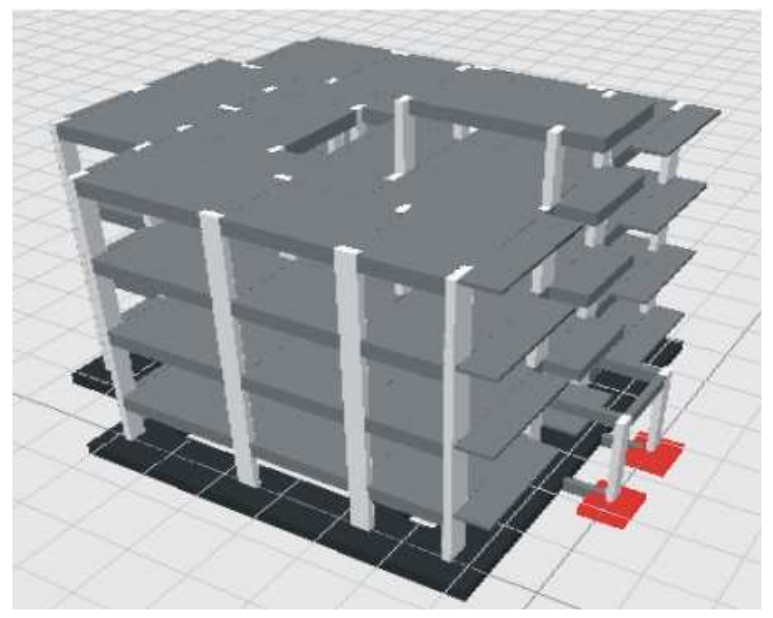

Fig. 3: Remodeled of existing building

Table 2: Actual concrete class in construction

\begin{tabular}{ll}
\hline Actual concrete class & C20 \\
Selected concrete class for structural design & C25 \\
\hline
\end{tabular}

Modeling approach: Linear and non-linear static analyses were performed by using software package program ideCAD version 5.511 (2007). This software is an integrated analysis, design and detailing software for reinforced concrete constructions specially developed for structural designers of tall buildings (deCAD, 2007) based on Turkish earthquake code (2007). Figure 3 shows the 3D model of the remodeled existing building. Beams, columns, slabs and foundation with their material properties, dimensions and reinforcement bars were entered to the program. Plastic hinges properties were defined as described in FEMA 356 at both ends of the beams and columns (M3 for beams and PMM for columns) as lumped plasticity.

\section{RESULTS AND DISCUSSION}

Weak columns: Linear static analyses were performed to detect the most critical regions in structure such as weak columns and not safety beam-column joints.

In structural systems comprised of frames only or of combination of frames and walls, sum of ultimate moment resistances of columns framing into a beamcolumn joint shall be at least $20 \%$ more than the sum of ultimate moment resistances of beams framing into the same joint should be satisfied (TEC, 2007):

$(\mathrm{Mra}+\mathrm{Mru}) \geq 1.2(\mathrm{Mri}+\mathrm{Mrj})$

$\mathrm{Nd} \leq(0.10)$. Ac.fck

Where:

Mra $=$ The moment resistance calculated at the bottom of column or wall clear height by considering fcd and fyd

Mru $=$ The ultimate moment resistance calculated at the top of column or wall clear height by considering fcd and fyd

Mrj $=$ The ultimate moment calculated at the column or shear wall face in the right end $\mathrm{j}$ of the beam

Mri = The ultimate moment calculated at the column or shear wall face in the left end $i$ of the beam

$\mathrm{Nd}=$ The factored axial force calculated under simultaneous action of vertical loads and seismic loads

Ac $=$ The gross cross-sectional area of the column $\left(\mathrm{cm}^{2}\right)$

Fck $=$ The characteristic compressive strength of the concrete used in the column $\left(\mathrm{kgf} \mathrm{cm}^{-2}\right)$ 
Am. J. Engg. \& Applied Sci., 3 (1): 109-116, 2010

Table 3: Detected weak columns: $+\mathrm{E}(\mathrm{y})$

\begin{tabular}{|c|c|c|c|c|c|c|c|}
\hline Structure type & Columns & $\begin{array}{l}\text { Mra + Mru } \\
\text { (ton.m) }\end{array}$ & $\begin{array}{l}1.2 \\
(\mathrm{Mri}+\mathrm{Mrj}) \\
\text { (ton.m) }\end{array}$ & $\begin{array}{l}\mathrm{Nd} \\
\text { (ton) }\end{array}$ & $\begin{array}{l}(0.10) \\
\text { Ac.fck } \\
\text { (ton) }\end{array}$ & $\begin{array}{l}\text { Earthquake } \\
\text { code }\end{array}$ & $\begin{array}{l}\text { Percentage of increased for } \\
\text { sum of ultimate moment } \\
\text { resistances of columns }\end{array}$ \\
\hline \multirow[t]{2}{*}{ Existing structure } & $\mathrm{S} 2 \mathrm{C}$ & 16.10 & 42.25 & 30.85 & 30 & & - \\
\hline & S7G & 26.64 & 29.78 & 58.72 & 50 & Weak & - \\
\hline \multirow[t]{2}{*}{ Jacketed structure } & $\mathrm{S} 2 \mathrm{C}$ & 53.74 & 42.24 & 44.26 & 72 & Columns & 233.79 \\
\hline & S7G & 48.64 & 29.78 & 64.21 & 77 & Strong & 82.58 \\
\hline \multirow[t]{2}{*}{ Steel braces } & $\mathrm{S} 2 \mathrm{C}$ & 16.29 & 42.25 & 28.01 & 30 & Columns & 1.18 \\
\hline & S7G & 29.31 & 29.28 & 60.41 & 50 & Strong & 10.02 \\
\hline \multirow[t]{2}{*}{ Shear walls } & $\mathrm{S} 2 \mathrm{C}$ & 15.07 & 12.74 & 25.53 & 30 & Columns & -6.40 \\
\hline & S7G & 23.50 & 22.16 & 42.28 & 50 & Strong columns & -11.79 \\
\hline
\end{tabular}

If both Eq. 2 and 3 are not satisfied, the related column is called weak column. Weak columns of the existing building under four earthquake load cases $(+\mathrm{EX},-\mathrm{EX},+\mathrm{EY}$ and $-\mathrm{EY})$ were detected. Totally two weak column were detected. The detected columns are for all stories are S2C and S7G. The dimension of S2C is $25 \times 60 \mathrm{~cm}$ and $\mathrm{S} 7 \mathrm{G}$ has a dimension of $25 \times 100 \mathrm{~cm}$. Table 3 gives the details of the detected weak columns according to linear performance analysis.

Column-beam joint safety analysis: According to Turkish earthquake code 2007, If the shear force calculated in the left or right end of the beam "Ve (+) or $\mathrm{Ve}(-)$ " are less than the maximum shear force that the joint can resist "Vemax", the shear safety is satisfied, if not it is not satisfied. There are totally twenty four not safety joints detected in assessed structure. For instance Table 4 summarizes the details of one of not safety column-beam joints (S2C):

$\mathrm{Ve}(+)=(1.25) \cdot \mathrm{fyk} \cdot($ As $1 \mathrm{j}+\mathrm{As} 2 \mathrm{i})-\mathrm{Vcol}$

$\operatorname{Ve}(-)=(1.25) \cdot f y k \cdot(A s 1 i+A s 2 j)-V c o l$

Ve $\max =$ x.bj.h.fcd

Where:

As $1 \mathrm{j}=$ The tension reinforcement in the upper right part of the $1 \mathrm{st}$ beam $\left(\mathrm{cm}^{2}\right)$

As1i $=$ The tension reinforcement in the upper right part of the 2nd beam $\left(\mathrm{cm}^{2}\right)$

As $2 \mathrm{j}=$ The tension reinforcement in the lower right part of the $1 \mathrm{st}$ beam $\left(\mathrm{cm}^{2}\right)$

As2i $=$ The tension reinforcement in the lower right part of the 2nd beam $\left(\mathrm{cm}^{2}\right)$

$\mathrm{Bj}=$ Double the amount of the smaller one of the distances from the middle axis of the beam connected to the joint, to the column edges, in the direction of investigation $(\mathrm{m})$

$\mathrm{Fcd}=$ Design compressive strength of concrete; $\mathrm{h}$ is the size of the column parallel to the direction of investigation $(\mathrm{m})$

$\mathrm{Vcol}=$ The smaller of the column shear forces calculated above and below the joint (ton)

Fyk $=$ Characteristic yield strength of longitudinal reinforcement $\left(\mathrm{kgf} \mathrm{cm}^{-2}\right)$ and $\times$ is taken 0.45 which is constant value for non-surrounded joints conditions

Strengthening of detected problems: Three common used strengthening techniques in North Cyprus were applied to the existing building to remove all detected problems mentioned in previous sections (Fig. 4). For jacketing of the columns, exception of S2C column, all columns edges increased five $\mathrm{cm}$, for S2C column, ten $\mathrm{cm}$ jacketing was used. The selected properties of steel braces were, modulus of elasticity $=21000000\left(\mathrm{t} \mathrm{m}^{-2}\right)$, safety stress $=16000\left(\mathrm{t} \mathrm{m}^{-2}\right)$ and area of steel braces is equal to $24 \mathrm{~cm}^{2}$. All added new shear wall have same thickness of $25 \mathrm{~cm}$. The used concrete compressive strength for all strengthening methods was same and equal to $20 \mathrm{MPa}(\mathrm{C} 20)$.

Effect of strengthening methods on weak columns: As Table 3 shows the column jacketing is the most effective method to remove the weak columns. Because column jacketing at the same time increased the column moment and axial force capacities (Mra + Mru and 0.10 Ac.fck) significantly which provide to the satisfaction of both Eq. 2 and 3. However, because of the increase in the column stiffness due to the column jacketing, the column's Nd increased. Since in the other two methods column size remained unchanged the column moment capacity did not increase and Eq. 2 did not satisfy. However, additional shear walls and steel braces reduced the column axial forces and led to satisfaction of Eq. 3. 
Am. J. Engg. \& Applied Sci., 3 (1): 109-116, 2010

Table 4: Not safety column-beam regions analysis

\begin{tabular}{lllllllllll}
\hline Building type & Column & As1j $(\mathrm{cm})$ & As2 $\left(\mathrm{cm}^{2}\right)$ & As2 $\mathrm{j}\left(\mathrm{cm}^{2}\right)$ & As1i $\left(\mathrm{cm}^{2}\right)$ & Vcol (ton) & Ve+ (ton) & Ve- (ton) & Vemax (ton) & Result \\
\hline Existing & S2C & 7.70 & 7.7 & 7.7 & 7.7 & 0.66 & 80.20 & 80.20 & 37.5 & Not safe \\
Jacketing & S2C & 7.70 & 7.7 & 7.7 & 7.7 & 4.25 & 76.57 & 76.57 & 121.5 & Safe \\
Steel brace & S2C & 7.70 & 7.7 & 7.7 & 7.7 & 0.32 & 80.50 & 80.50 & 37.5 & Not safe \\
Shear wall & S2C & 4.62 & - & 3.8 & - & 0.37 & 23.87 & 15.79 & 37.5 & Safe \\
\hline
\end{tabular}

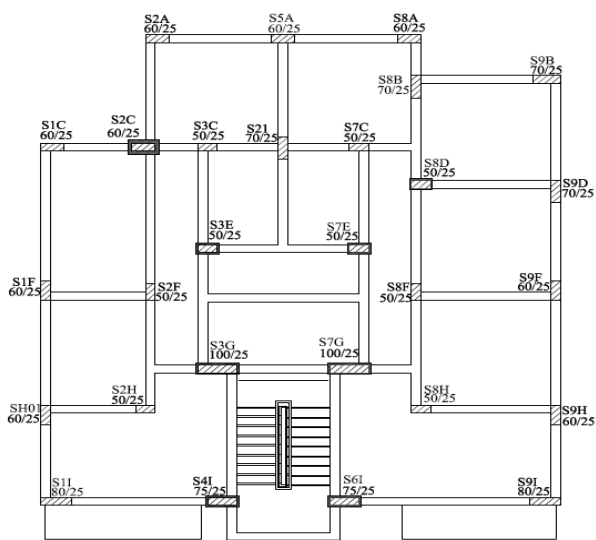

(a)

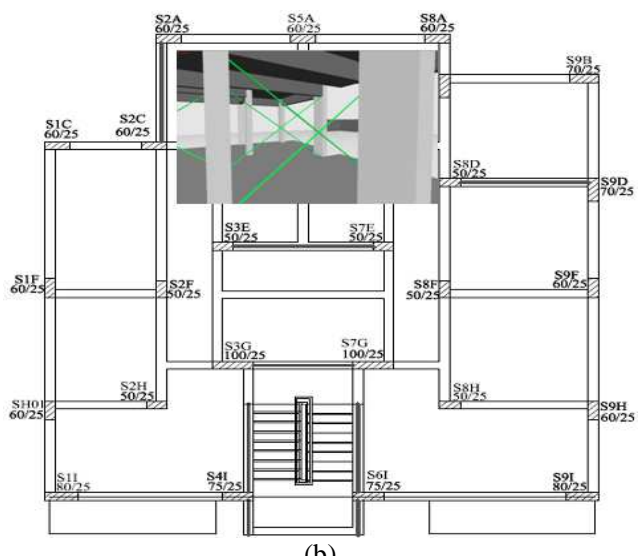

(b)

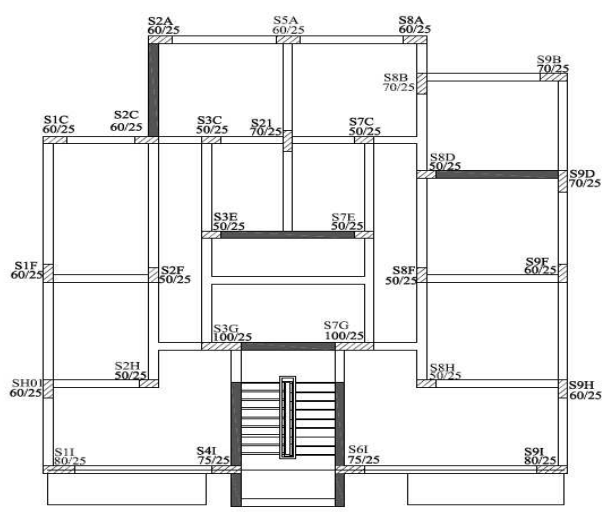

(c)

Fig. 4: Three used strengthening technique: (a) column jacketing; (b) adding steel brace; (c) adding new shear walls
Table 5: Linear performance analysis result: $+\mathrm{E}(\mathrm{x})$

\begin{tabular}{|c|c|c|c|c|c|}
\hline \multirow[b]{2}{*}{ Story } & \multirow[b]{2}{*}{$\begin{array}{l}\text { Structural } \\
\text { elements }\end{array}$} & \multicolumn{4}{|l|}{ Zone } \\
\hline & & $\begin{array}{l}\text { Minimum } \\
\text { damage }\end{array}$ & $\begin{array}{l}\text { Evident } \\
\text { damage }\end{array}$ & $\begin{array}{l}\text { Further } \\
\text { damage }\end{array}$ & Collapse \\
\hline \multirow[t]{2}{*}{3 th floor } & Beams & $44(98 \%)$ & - & - & $1(2 \%)$ \\
\hline & Columns & $28(100 \%)$ & - & - & - \\
\hline \multirow[t]{2}{*}{ 2nd floor } & Beams & $38(84 \%)$ & $2(4 \%)$ & $1(2 \%)$ & $4(9 \%)$ \\
\hline & Columns & $28(100 \%)$ & - & - & - \\
\hline \multirow[t]{2}{*}{ 1th floor } & Beams & $27(60 \%)$ & $7(16 \%)$ & - & $11(24 \%)$ \\
\hline & Columns & $28(100 \%)$ & - & - & - \\
\hline Ground & Beams & $30(67 \%)$ & $5(11 \%)$ & $2(4 \%)$ & $8(18 \%)$ \\
\hline floor & Columns & $30(67 \%)$ & - & - & - \\
\hline
\end{tabular}

Effect of strengthening methods on not safety shear joints: Table 4 compares the effect of each strengthening method on the joint shear safety results. Among three methods column jacketing was more effective to increase the joint shear safety. Because increasing the column size, directly increases the joint shear capacity (Vemax). However it can also slightly reduce the shear demand ( $\mathrm{Ve}+$ or $\mathrm{Ve}-$ ) which is due to the increase in the Vcol. Steel braces did not provide any improvement in the shear safety of joints since they did not affect the shear capacity of joints (Vemax). However, steel braces slightly increased the shear demand at beams due to the reduction in Vcol. However, shear walls are not able to increase the Vemax, but they reduced the shear demands at beams. It finally let to achievement adequate shear safety of joint.

Effect of strengthening methods on building performance based on (Sucuoglu, 2006): Based on the proposed procedure by Sucuoglu (2006), the performance level of a structure at a given earthquake direction $(+\mathrm{EX},-\mathrm{EX},+\mathrm{EY}$ and $-\mathrm{EY})$ determines with respect to the damage limit of its structural elements. Damage limits of the structural elements classify as minimum damage limit (MN), Safety limit (SF) and Collapse Limit (CL) as shown in Fig. 5. For instance, Table 5 summarizes the expected damage limits in structure elements of the existing RC building at the Design Based Earthquake hazard level (DBE) in +EX earthquake direction. Table 6 compares the performance levels of the existing and the three strengthened buildings at four considered earthquake directions. 
Am. J. Engg. \& Applied Sci., 3 (1): 109-116, 2010

Table 6: Performance levels of four building types

\begin{tabular}{lllll}
\hline Type & $+\mathrm{E}(\mathrm{x})$ & $-\mathrm{E}(\mathrm{x})$ & $+\mathrm{E}(\mathrm{y})$ & $-\mathrm{E}(\mathrm{y})$ \\
\hline Existing & Collapse & Collapse & $\mathrm{CP}$ & $\mathrm{CP}$ \\
Jacketing & Collapse & Collapse & $\mathrm{CP}$ & $\mathrm{CP}$ \\
Steel brace & Collapse & Collapse & $\mathrm{CP}$ & $\mathrm{CP}$ \\
Shear wall & $\mathrm{CP}$ & $\mathrm{CP}$ & $\mathrm{CP}$ & $\mathrm{CP}$ \\
\hline
\end{tabular}

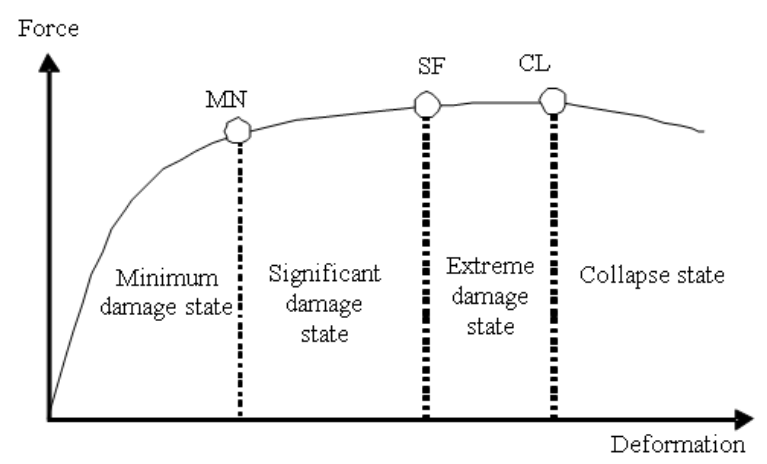

Fig. 5: Damage limits and damage states in a ductile member (Sucuoglu, 2006)

Results showed that the existing building is weaker in $\mathrm{X}$ direction when was compared to $\mathrm{Y}$ direction. The performance level in $\mathrm{X}$ direction was collapse whilst the expected performance level in $\mathrm{Y}$ direction was determined as collapse prevention. Table 6 indicates that only adding shear walls could slightly increase the performance level of the existing building whilst other methods were failed. Based on these results it can be concluded that the strengthening procedures which are based on the removing of weak columns and not shear safe joints, may not be able to improve the level of building performance. In other word, the strengthening procedures should be based on nonlinear analyses with respect to the progress of plastic hinge formations in beams and columns.

Effect of strengthening methods on building performance based on FEMA 356 procedure: After the strengthening of the existing building which was based on the linear static procedure, nonlinear pushover analyses were carried out following the FEMA356's NSP for evaluating the structural seismic response. The pushover (base shear-lateral displacement at control node) curves were established by application of gravity loads and two lateral load patterns (modal distribution and uniform distribution) in both $X$ and $\mathrm{Y}$ direction. The structural demands such as base shear, roof displacement, roof drift ratio and number of elements in difference performance levels, IO, LS and $\mathrm{CP}$ at the FEMA356 performance point for all building types are calculated and presented in Table 7.

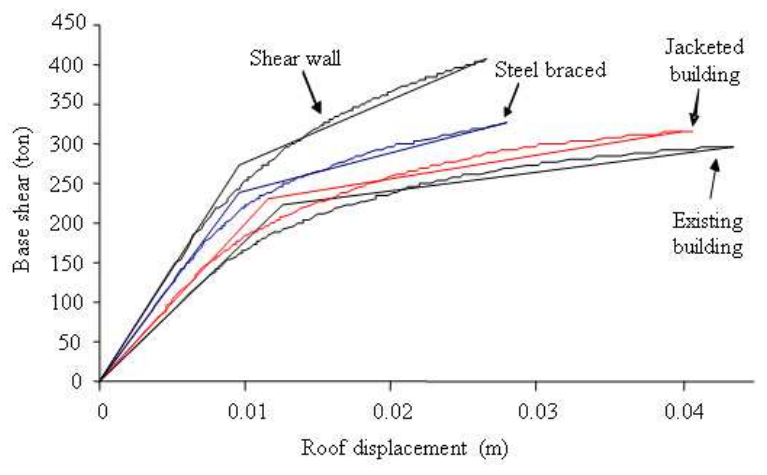

Fig. 6: FEMA 356 idealized pushover curves for different building types

The performance point was determined as the displacement at the control node (the center of mass of the building's roof) reaches the target displacement (Eq. 7) defined in FEMA 356:

$\delta_{\mathrm{t}}=\mathrm{C}_{0} \mathrm{C}_{1} \mathrm{C}_{2} \mathrm{C}_{3} \mathrm{~S}_{\mathrm{a}} \frac{\mathrm{T}_{\mathrm{e}}^{2}}{4 \pi^{2}} \mathrm{~g}$

Where:

$\mathrm{C}_{0}=$ Ratio between the MDOF roof displacement and the SDOF elastic spectral response

$\mathrm{C}_{1}=$ Ratio between the expected maximum displacement of the inelastic SDOF oscillator with Elastic Perfectly Plastic (EPP) hysteretic to the displacements calculated for linear elastic response

$\mathrm{C}_{2}=$ Factor that accounts for deviations of the hysteretic response from the ideal EPP behavior

$\mathrm{C}_{3}=$ Amplification factor for P- $\Delta$ effects

The factor $\mathrm{C}_{3}$ has been suspect to be near one based on works done in (Jennings and Husid; Bernal, 1992; Bernal, 1998). The remaining variables in Eq. 3 are $\mathrm{Sa}=$ Elastic response spectrum acceleration at the fundamental period of the building and $\mathrm{g}=$ acceleration of gravity.

As Table 7 and Fig. 6 shows all strengthening methods increased the building base shear at yield and FEMA356 performance point. Whilst they reduced the maximum expected roof displacement at these two points. However, the shear walls were more effective than other strengthening methods in this purpose. Table 7 also summarizes the maximum roof drift ratio for different building at FEMA356 performance point. As Table 7 shows all building have roof drift ratio (maximum roof displacement/building height) less than 0.5 which indicates that all buildings are in IO performance level. 
Am. J. Engg. \& Applied Sci., 3 (1): 109-116, 2010

Table 7: Structural demand at FEMA356 performance point for + EX (lateral load pattern = modal distribution)

\begin{tabular}{|c|c|c|c|c|c|c|c|c|c|c|}
\hline \multirow[b]{3}{*}{ Building type } & \multirow[t]{3}{*}{ ormance } & \multirow{3}{*}{$\begin{array}{l}\text { Roof drift } \\
\Delta(\mathrm{m})\end{array}$} & \multirow{3}{*}{$\begin{array}{l}\text { Ductility } \\
\text { ratio }(\%)\end{array}$} & \multirow{2}{*}{\multicolumn{7}{|c|}{ Performance of push over of ground floor beams (\%) }} \\
\hline & & & & & & & & & & \\
\hline & & & & Ratio & A-B & $\mathrm{B}-\mathrm{IO}$ & IO-LS & LS-CP & $\mathrm{CP}-\mathrm{C}$ & $>\mathrm{C}$ \\
\hline Existing & 295 & 0.0434 & 0.380 & 3.47 & 60.00 & 33.33 & 0 & 0 & 0 & 6.67 \\
\hline Jacketing & 315 & 0.0399 & 0.351 & 3.50 & 63.33 & 31.67 & 0 & 0 & 0 & 5.00 \\
\hline Steel bracing & 324 & 0.0279 & 0.245 & 2.93 & 82.14 & 14.29 & 0 & 0 & 0 & 3.57 \\
\hline Shear wall & 404 & 0.0264 & 0.232 & 2.78 & 77.17 & 21.74 & 0 & 0 & 0 & 1.09 \\
\hline
\end{tabular}

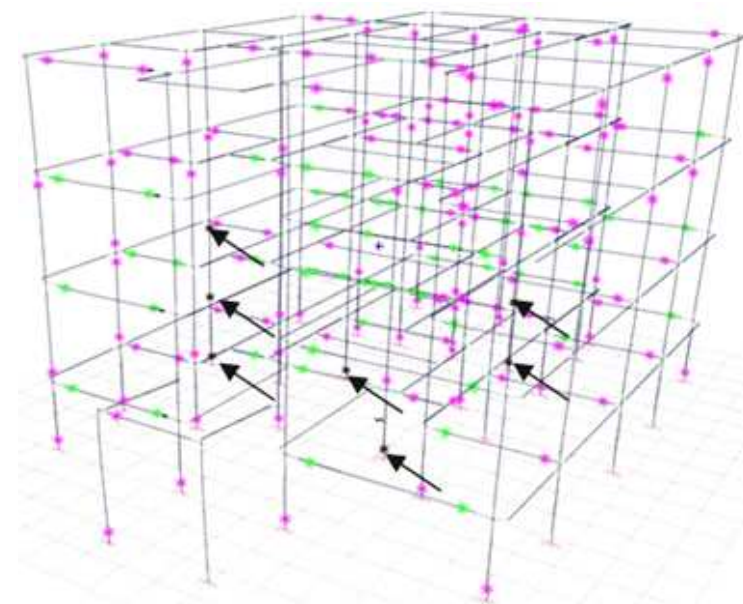

(a)

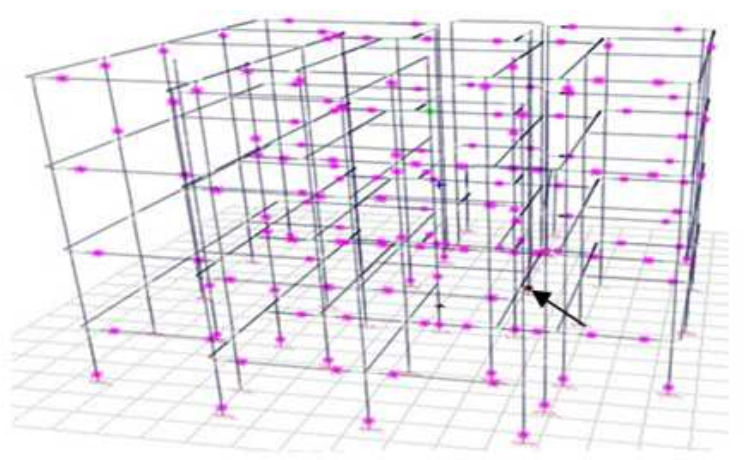

(b)

Fig. 7: Plastic hinge distribution: (a) existing building; (b) strengthened building using shear walls. (= collapse)

Ductility ratio (ultimate roof displacement/yield roof displacement) is a parameter which can represent the building ductility capacity. As Fig. 6 and Table 7 shows column jacketing technique caused the highest ductility ratio whilst shear walls significantly reduced the ductility ratio. Table 7 shows that by strengthening of the building, the number of structure elements in elastic region (A-B or B-IO) increases and number of collapsed elements reduce. It finally leads to increase in the building performance level. Adding shear walls caused the maximum reduction in number of collapsed elements at FEMA356 performance point.

Figure 7 compares the plastic hinge formation of existing and strengthened building in the presence of shear walls. As Fig. 7 shows additional shear walls were effective to reduce the number of plastic hinges in collapse region.

\section{CONCLUSION}

This study aimed to investigate the effectiveness of common strengthening techniques used in North Cyprus. These methods include column jacketing, adding steel braces and new shear walls. For this purpose an existing 4 four story RC was remodeled and all different strengthening methods were applied.

Results showed that however both the column jacketing and adding shear walls are able to remove the weak columns and increase the shear safety of beamcolumn joints, but column jacketing is much more effective. Steel braces just were able to remove the weak columns and could not improve the shear safety of the beam column joints. Nonlinear static pushover results showed that all three methods and particularly shear walls increase the base shear and reduce the maximum roof displacement and number of collapsed elements at FEMA356 performance point. However, adding shear walls caused a remarkable reduction in ductility ratio. Results showed the negligible effect of the three selected strengthening methods on improving the building performance based on the proposed procedure in Turkish earthquake code. It is due to the high restriction of this procedure in representing the performance level of a building. In this method even there is only one collapsed element the performance level will be considered as collapse. Therefore it can be concluded that push-over analysis plays an important role during strengthening of structures in order to make a correct decision for strengthening technique. The most buildings in North Cyprus are between four or five stories which indicate they have limited displacement at roof. Therefore adding new shear walls may not be necessary to limit maximum roof displacements. However in compare to other methods, 
adding new shear walls are more expensive since in this method additional foundation should be provided. Therefore, based on these results it might be concluded that the column jacketing is the most effective and the most economic strengthening method for low rise buildings in North Cyprus. It should be noted that, in this study only detected not safety column-beam joints and weak columns have been strengthened and compared based on minimum earthquake code requirements. As it is known that the best strengthening technique is when whole structure is considered.

\section{REFERENCES}

Bertero, R.D. and V.V. Bertero, 2002. Performancebased seismic engineering: The need for a reliable conceptual comprehensive approach. Earthquake Eng. Struct. Dyn., 31: 627-652. DOI: 10.1002/eqe. 146

Bernal, D., 1992. Instability of buildings subjected to earthquakes. J. Struct. Eng. ASCE, 188: 22392260. DOI: 10.1061/(ASCE)0733-9445

Bernal, D., 1998. Instability of buildings during seismic response. Eng. Struct., 20: 496-502. DOI: 10.1016/S0141-0296(97)00037-0

FEMA., 2000. Prestandard and commentary for the seismic rehabilitation of buildings. FEMA., Washington DC., USA.

http://www.fema.gov/library/viewRecord.do?id=14 27
IdeCAD., 2007. Structural 5.511 enterprise software program. http://www.idecad.com.tr

Jennings, P.C. and R. Husid, 1968. Collapse of yielding structures under earthquakes. J. Eng. Mech. ASCE, 94: 1045-1065.

Sucuoglu, H., 2006. The Turkish seismic rehabilitation code. Proceeding of the First European Conference on Earthquake Engineering and Seismology, Sept. 2006, Geneva, Switzerland, pp: 3.

TEC., 2007. Turkish earthquake code for buildings. Ministry of Public Works and Settlement, Ankara, Turkey. 